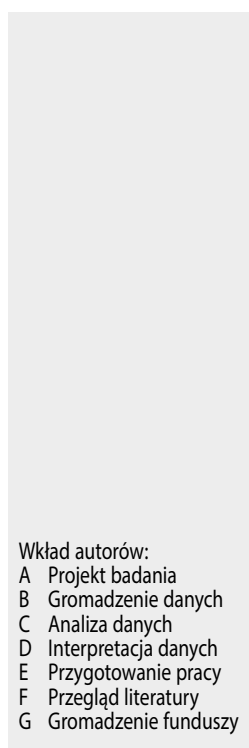

\title{
Muzykoterapia u dorosłych użytkowników implantów ślimakowych. Przegląd piśmiennictwa
}

\section{Music therapy for adult cochlear implant users. Literature review}

\author{
Katarzyna Godlewska ${ }^{1,2 B-F}$, Barbara Kaczyńska ${ }^{1,2 B E F, ~}$ \\ Henryk Skarżyński ${ }^{1 C D G}$ \\ ${ }^{1}$ Instytut Fizjologii i Patologii Słuchu, Światowe Centrum Słuchu, Klinika Oto-Ryno- \\ -Laryngochirurgii, Kajetany \\ ${ }^{2}$ Instytutu Fizjologii i Patologii Słuchu, Światowe Centrum Słuchu, Klinika Rehabilitacji, \\ Kajetany
}

\begin{abstract}
Streszczenie
Celem pracy był przegląd piśmiennictwa pod kątem zastosowania muzykoterapii w rehabilitacji dorosłych pacjentów, którzy są użytkownikami implantów ślimakowych. Artykuły wyszukano w bazie publikacji PubMed. Z uwagi na niewielką liczbę dostępnych publikacji nie wyznaczono ram czasowych. Po zastosowaniu kryteriów włączających i wyłączających ostatecznie analizie szczegółowej poddano 5 artykułów na temat programów muzykoterapeutycznych przeznaczonych dla dorosłych pacjentów, którzy są użytkownikami implantów ślimakowych. Prace badawcze autorów dotyczyły ćwiczeń usprawniających funkcje słuchowe przy pomocy dźwięków muzyki. Zajęcia muzykoterapeutyczne miały różne formy - były prowadzone indywidualnie lub grupowo, w ośrodku rehabilitacyjnym lub w domu pacjenta, przy użyciu muzyki na żywo lub dźwięków uprzednio nagranych i elektronicznie przetworzonych. Wyniki osiągnięte $w$ ramach przeprowadzonych terapii wskazują na poprawę podstawowych funkcji słuchowych: detekcji, dyskryminacji, rozumienia dźwięków i pamięci słuchowej, co dowodzi zasadności zastosowania muzyki w rehabilitacji dorosłych użytkowników implantów ślimakowych.
\end{abstract}

Słowa kluczowe: muzykoterapia • implant ślimakowy • dorośli

\begin{abstract}
The aim of the study is to review the literature on use of music therapy in the rehabilitation of adult patients who are users of cochlear implants. The articles, the analysis of which is presented in this review of literature, have been searched in the PubMed publication database. Due to the small number of available publications, no time frame was set for the published ones. After the analysis of the searched papers and application of inclusion and exclusion criteria to them, 5 articles were subjected to detailed analysis. They concerned music therapy programmes for adult patients who are users of cochlear implants. The research work of the authors was based on the exercise of improving listening functions with the help of music sounds. The classes took different forms: individual and group, in a rehabilitation centre or at the patient's home, using live music or sounds previously recorded and electronically processed. The results achieved in the conducted therapies indicate an improvement of basic listening functions: detection, discrimination, sound understanding and auditory memory, which proves the validity of using music in the rehabilitation of adult cochlear implant users. Key words: music therapy $\bullet$ cochlear implant $\bullet$ adults
\end{abstract}

Adres autora: Katarzyna Godlewska, Klinika Rehabilitacji, Światowe Centrum Słuchu, Instytut Fizjologii i Patologii Słuchu, ul. Mokra 17, 05-830, Nadarzyn, e-mail: k.godlewska@ifps.org.pl 


\section{Wstęp}

Zrozumienie mechanizmu przetwarzania muzyki przez mózg ludzki jest ogromnym wyzwaniem współczesnej neurobiologii [1]. Wiadomo, że jest to proces bardzo skomplikowany, który nie odbywa się w jednym konkretnym miejscu, ale angażuje wiele różnych obszarów centralnego układu nerwowego (CUN) [2]. Każdy utwór muzyczny składa się z kilku elementów. Główne z nich to: rytm, melodia i harmonia. Rytm zależy od długości trwania dźwięków, ich ilości w jednostce czasu i odpowiedniej powtarzalności cyklów złożonych z uderzeń mocnych (akcentowanych) i słabych (nieakcentowanych). Melodia to połączenie dźwięków różniących się od siebie wysokością, a harmonia jest efektem nakładania się ich i współbrzmienia [3]. Każdy z tych elementów interpretowany jest w inny sposób w różnych miejscach kory słuchowej [1]. W rehabilitacji osób z problemami ze słuchem wykorzystuje się różne metody terapeutyczne, w tym muzykoterapię. Terapia ta opiera się na zjawisku neuroplastyczności mózgu, czyli jego zdolności do zmian strukturalnych i funkcjonalnych w zależności od bodźców, jakie otrzymuje. W przypadku nieleczonego niedosłuchu mózg otrzymuje ich za mało, natomiast np. w przypadku zastosowania implantu ślimakowego, a w części przypadków - aparatu słuchowego, dociera ich znacznie więcej niż zazwyczaj [4].

Uszkodzenie narządu słuchu może wystąpić w każdym okresie życia. Może być wrodzone - uwarunkowane genetycznie lub spowodowane czynnikami pozagenetycznymi, np. trudnościami okołoporodowymi czy infekcjami przebytymi przez matkę w czasie ciąży, lub nabyte - przede wszystkim wskutek infekcji [5,6]. W zależności od czasu wystąpienia wyróżniamy kilka typów niedosłuchu:

1. Niedosłuch prelingwalny (przedjęzykowy), spowodowany uszkodzeniami w okresie zarodkowym i płodowym.

2. Niedosłuch perilingwalny (okołojęzykowy), spowodowany uszkodzeniami układu słuchowego w okresie rozwoju mowy.

3. Niedosłuch postlingwalny (pojęzykowy), spowodowany uszkodzeniem słuchu po zakończeniu rozwoju mowy, gdy opanowane zostały przynajmniej podstawy mowy i języka [7].

Trudności komunikacyjne wynikające $\mathrm{z}$ niedosłuchu zależą od momentu jego wystąpienia. Określenie dokładnego wieku, w którym kończy się jeden, a rozpoczyna kolejny etap rozwoju językowego, nie jest proste. Szacuje się, że okres postlingwalny to u zdrowego dziecka ok. 5-6 rok życia - wtedy zaczyna czytać i pisać. Granica między stadium pre- i perilingwalnym nie jest wyraźnie zaznaczona. Wiadomo jednak, że pojawiający się wtedy niedosłuch jest poważnym zagrożeniem dla prawidłowego rozwoju języka biernego. Dziecko, ponieważ nie słyszy lub głęboko niedosłyszy, nie uczy się znaczenia podstawowych słów, takich jak np. mama, tata, papa itp., nie reaguje też na własne imię. Naturalną konsekwencją niewykształcenia się słownika biernego jest nieumiejętność jego stosowania w sposób czynny. Dziecko około 12 miesiąca przestaje gaworzyć i zaczyna komunikować się na drodze wzrokowo-gestowej [8].
W literaturze pojawiają się informacje na temat dwóch głównych sposobów stosowania muzyki w terapii słuchu: analitycznego i syntetycznego. Sposób analityczny polega na wprowadzaniu stopniowo coraz trudniejszych ćwiczeń odnoszących się bezpośrednio do funkcji słuchowych, np. różnicowanie instrumentów na podstawie barwy lub wysokości dźwięku. Natomiast muzykoterapia stosowana w sposób syntetyczny ma wpływać nie tylko na rozwój funkcji słuchowych, lecz także na ogólny rozwój funkcji poznawczych, np. uwagi, myślenia, pamięci. Ćwiczenia w tym zakresie polegają zazwyczaj na słuchaniu złożonych utworów muzycznych i nauce rozpoznawania poszczególnych cech dźwięków. Są to np. ćwiczenia uwagi słuchowej, ćwiczenia percepcji rytmu, zmian melodii.

Oba te podejścia nie wykluczają się nawzajem, ponieważ ćwiczenia działają na różne wyżej wymienione funkcje (słuchowe, poznawcze itp.) i przynoszą różne korzyści. Optymalny program terapeutyczny powinien zawierać zarówno elementy analityczne, odwołujące się do podstawowych funkcji słuchowych, jak i syntetyczne, które pomagają kompensować trudności w odbiorze dźwięków, a zwłaszcza dźwięków nawarstwiających się, w trudnych warunkach akustycznych [1].

\section{Cel pracy}

Celem pracy był przegląd dostępnego piśmiennictwa na temat zastosowania muzykoterapii w rehabilitacji dorosłych pacjentów, którzy są użytkownikami implantów ślimakowych.

\section{Materiał i metody}

Dokonano przeglądu literatury zawartej w bazie artykułów naukowych PubMed. Kombinacja słów kluczowych (music therapy, adults, cochlear implant) umożliwiła wyszukanie 65 prac. Z uwagi na ograniczoną liczbę publikacji nie wyznaczono ram czasowych wyszukiwania. Kryterium włączającym były artykuły w języku polskim i angielskim dotyczące muzykoterapii u osób dorosłych z implantami ślimakowymi. Wyszukane prace były analizowane na podstawie tytułu, streszczenia oraz pełnego tekstu. Po wykluczeniu prac, które nie opisywały procesu terapeutycznego, lecz charakterystykę odbioru muzyki przez implant ślimakowy (27 artykułów), działanie i użytkowanie implantów ślimakowych (30 artykułów), wpływ muzykoterapii na szumy uszne ( 3 artykuły), pozostało 5 artykułów. W badaniach łącznie wzięło udział 97 dorosłych użytkowników implantów ślimakowych Wszystkie prace zostały opublikowane w języku angielskim. Nie znaleziono doniesień na ten temat w języku polskim. Zajęcia muzykoterapii przybierały różne formy: ćwiczeń z muzykoterapeutami (podczas których używano szerokiej gamy instrumentów muzycznych), ćwiczeń rehabilitacyjnych w domu pacjenta lub wykorzystywania autorskich programów komputerowych przeznaczonych dla tej grupy odbiorców.

\section{Wyniki}

\section{Bjørn Petersen i wsp. (2012 r.)}

Autorzy zebrali grupę 18 pacjentów i podzielili ją na dwie podgrupy: badaną i kontrolną [9]. W grupie badanej 
znalazło się 6 kobiet i 4 mężczyzn (średnia wieku 47 lat), natomiast grupa kontrolna składała się z 4 kobiet i 5 mężczyzn (średnia wieku 59 lat). Średnia długość korzystania z implantu ślimakowego wynosiła 29 lat. Program, dostosowany do indywidualnych potrzeb każdego pacjenta, trwał 6 miesięcy i obejmował godzinne spotkania $\mathrm{z}$ muzykoterapeutą raz $\mathrm{w}$ tygodniu oraz indywidualną pracę $\mathrm{w}$ domu $\mathrm{z}$ wykorzystaniem programu komputerowego. Pacjenci byli badani po 3 miesiącach od momentu rozpoczęcia rehabilitacji i po jej zakończeniu. Wszyscy pacjenci wypełniali kwestionariusz oceniający ich doświadczenie muzyczne. Celem pracy była ocena zastosowania muzykoterapii jako formy rehabilitacji dorosłych użytkowników implantów ślimakowych.

Pacjenci podczas rehabilitacji domowej pracowali nad:

a) rozpoznawaniem instrumentów muzycznych: słuchanie otrzymanego materiału muzycznego (piosenek) i rozpoznawanie, na jakim instrumencie grana jest melodia;

b) identyfikacją konturu melodycznego (rozpoznawanie jednego z 3 instrumentów należących do różnych grup: flet, fortepian i kontrabas);

c) dyskryminacją wysokości dźwięków prezentowanych przy pomocy instrumentów (klarnet, skrzypce, trąbka, puzon, gitara);

d) rozróżnianiem rytmu;

e) dyskryminacją melodii.

Muzykoterapia pod okiem specjalisty polegała na:

a) śpiewaniu: wokalizowaniu i naśladowaniu krótkich fraz z całą gamą samogłosek, śpiewaniu znanych piosenek; kładziono nacisk na precyzję, artykułowanie tekstów i intonację;

b) graniu na instrumentach;

c) odwzorowywaniu podanego rytmu: gra na bębenku, stukanie w perkusję, a na późniejszym, a zarazem trudniejszym etapie - artykułowanie tekstów i rytmu.

Każdy z uczestników został zbadany za pomocą testu mowy Hagermana [9] oraz testu rozpoznawania prozodii emocjonalnej, w którym pacjent oceniał prozodię 44 różnie wypowiadanych słów i zdań oraz oceniał emocje/uczucia towarzyszące terapeucie, który je wypowiadał. Wyniki w grupie badanej wykazały poprawę: zdolności różnicowania barwy dźwięku, rozpoznawania konturu melodycznego, dyskryminacji wysokości oraz rytmu, jak również jakości percepcji muzyki [9].

\section{Elisabeth Hutter i wsp. (2015 r.)}

Autorzy zaproponowali 10 zindywidualizowanych $50 \mathrm{mi}-$ nutowych sesji muzykoterapeutycznych uwzględniających potrzeby pacjenta [10]. Wszyscy badani byli użytkownikami implantów ślimakowych wszczepionych w Klinice Laryngologii Szpitala Uniwersyteckiego w Heidelbergu w okresie od lutego 2012 r. do stycznia 2013. Pacjenci byli włączani do zajęć muzykoterapeutycznych 5-6 tygodni po aktywacji systemu implantu ślimakowego. W badaniu wzięło udział 19 osób. Średni wiek wynosił 54 lata. Wszyscy znajdowali się pod stałą opieką audiologa, logopedy oraz inżynierów protetyki słuchu. Celem pracy było zbadanie wpływu muzykoterapii na zdolność różnicowania dźwięków oraz na poprawę jakości komunikowania się. W badaniu zastosowano kwestionariusze w celu oceny: subiektywnej zdolności słyszenia (odbioru dźwięku przez implant ślimakowy), postrzegania samego siebie oraz subiektywnej oceny efektów muzykoterapii. Muzykoterapia obejmowała 5 modułów:

1. Zmienność głosu i mowy: w ćwiczeniach kładziono nacisk na poprawę rozumienia mowy i jej produkcji, zwłaszcza prozodii mowy.

2. Elementy składowe muzyki: nauka różnicowania wysokości, barwy i rytmu.

3. Mowa spontaniczna: praca nad poprawą rozumienia mowy poprzez umiejętność odczytywania mowy z ruchu warg.

4. Mowa w różnych warunkach akustycznych: trening polegał na zdobyciu umiejętności rozmowy w trudnych warunkach akustycznych (np. w hałasie, na przyjęciu).

5. Całościowe słyszenie: nabywanie umiejętności wyodrębniania mowy w różnym otoczeniu akustycznym.

Podczas zajęć muzykoterapeutycznych terapeuta grał na pianinie dwa dźwięki różniące się wysokością. Zadaniem pacjentów była ocena, czy dźwięk pierwszy był wyższy / niższy / taki sam jak dźwięk drugi. W kolejnym etapie zwiększono poziom trudności - muzykoterapeuta grał na fortepianie znane pieśni ludowe, a pacjenci musieli podać tytuł piosenki oraz zanucić melodię. Następnym zadaniem było zidentyfikowanie barwy dźwięku 8 nagranych utworów muzycznych wykonywanych przez jeden instrument solowy, kilka instrumentów z tej samej kategorii lub instrument solowy $\mathrm{z}$ akompaniamentem. Uczestnicy badania musieli nazwać lub opisać instrument lub całą kategorię (np. instrumenty smyczkowe, dęte, klawiszowe, perkusyjne). Wyniki badania przedstawiały się następująco: przed zajęciami możliwości słuchowe pacjenci ocenili jako słabe, natomiast po terapii - jako dobre. Wśród uczestników nastąpił wzrost samooceny oraz samoakceptacji, odnotowano także wysokie zadowolenie z terapii i jej efektów. Większość pacjentów oceniła, że ich sprawność słuchu poprawiła się, a co więcej muzykoterapia pozytywnie wpłynęła na ich koncentrację oraz dobre samopoczucie. Efektem uczestniczenia w zajęciach muzykoterapeutycznych było zwiększenie umiejętność różnicowana barwy oraz wysokości dźwięków [10].

\section{Kate Gfeller i wsp. (2016 r.)}

W badaniu Gfeller i wsp. wzięło udział 20 osób ogłuchłych postlingwalnie [11], użytkowników implantów ślimakowych przez okres 12-15 miesięcy. W grupie badanej znalazło się 11 osób (6 kobiet, 5 mężczyzn; średnia wieku 57 lat). Natomiast grupę kontrolną stanowiło 9 osób (5 kobiet, 4 mężczyzn; średnia wieku 56 lat), które nie uczestniczyły w muzykoterapii. Żaden z pacjentów nie miał doświadczenia muzycznego. Celem pracy była ocena zastosowania muzykoterapii do nauki różnicowania barwy dźwięków. Program muzykoterapii trwał 12 tygodni. Zajęcia polegały na ćwiczeniu umiejętności różnicowania barwy dźwięków. Pacjenci pracowali w domu przy pomocy programu komputerowego. Ćwiczenia polegały na odsłuchiwaniu melodii granej przez omówioną wcześniej grupę instrumentów (smyczkowe, dęte itp.) i wskazywaniu prawidłowej z nich. Pacjenci musieli także określić, jaka muzyka 
jest charakterystyczna dla danego instrumentu oraz z jakiego tworzywa dany instrument jest zrobiony. Na początku prezentowane były pojedyncze dźwięki (instrumenty solo), a z każdym kolejnym tygodniem stopień trudności ćwiczeń się zwiększał (podawano dźwięki złożone). Wyniki: grupa badana osiągnęła lepsze wyniki w różnicowaniu barwy dźwięków po zastosowaniu 12 tygodniowego treningu w porównaniu do grupy kontrolnej [11].

\section{Leah Smith i wsp. (2017 r.)}

Autorzy badaniami objęli 21 pacjentów (17 kobiet oraz 7 mężczyzn). Średnia wieku wynosiła 57 lat [12]. Wszyscy korzystali z implantu ślimakowego średnio 2 lata. Muzykoterapia była prowadzona raz w tygodniu przez okres 4 tygodni. Każda sesja trwała 2 godziny. Pacjenci wypełniali kwestionariusze oceniające zdolności oraz doświadczenie muzyczne. Następnie byli poddawani testom muzycznym przeprowadzanym w ciszy i hałasie. Celem pracy była ocena wpływu uczestniczenia w zajęciach muzykoterapii na wzrost odczuwanej przyjemności ze słuchania muzyki oraz na dyskryminację wysokości i barwy dźwięków. Zajęcia muzykoterapii opierały się na wykorzystaniu programu HearTunes składającego się z 3 modułów:

1. Moduł pierwszy składał się z 12 utworów (muzyka jazzowa, popowa i klasyczna) trwających 30 sekund: pacjenci mieli za zadanie odsłuchać utwory.

2. Moduł drugi składał się z dwóch części - dyskryminacji wysokości dźwięków i dyskryminacji barwy dźwięków. W pierwszej części uczestnikom prezentowano 32 pary dźwięków, a zadaniem pacjentów była ocena wysokości dźwięków (wyższy / niższy / taki sam jak poprzedni). W drugiej - prezentowano 20 par kompozycji o różnej barwie (instrumenty strunowe, dęte itp.), a zadaniem było rozpoznanie barwy.

3. Moduł trzeci składał się z 4 elementów: rozpoznawania schematów jedno i czterodźwiękowych, utworów $\mathrm{w}$ dwuwierszowych melodiach, utworów w muzyce trójwierszowej, kompozycji w muzyce dwuwierszowej, które wymagają podzielnej uwagi.

Wyniki badań wykazały poprawę dyskryminacji wysokości i barwy dźwięków oraz poprawę rozpoznawania schematów dźwiękowych. Natomiast pacjenci zaczęli odczuwać przyjemność ze słuchania muzyki. Program HearTunes, w opinii autorów, może stać się nowym narzędziem do rehabilitacji dorosłych użytkowników implantów ślimakowych [12].

\section{Christina Fuller i wsp. (2018 r.)}

Autorzy zastosowali muzykoterapię u 19 dorosłych użytkowników implantów ślimakowych ogłuchłych postlingwalnie [13]. Badanie trwało 8 tygodni. Kryterium włączającym było użytkowanie implantu ślimakowego dłużej niż rok, pacjenci nie mogli mieć współistniejących schorzeń neurologicznych. Średni wiek pacjentów wynosił 69 lat. Średnia długość korzystania $\mathrm{z}$ implantu ślimakowego wynosiła 6 lat. Celem badania było porównanie dwóch różnych podejść terapeutycznych oraz ocena ich wpływu na percepcję muzyki i mowy.

Uczestników badania podzielono na 3 grupy.
1. W pierwszej grupie zastosowano trening rozpoznawania wysokości i barwy dźwięku (dwugodzinne treningi komputerowe). Początkowo zadaniem uczestników było zidentyfikowanie instrumentu wydającego dany dźwięk (glockenspiel, fortepian, organy, klarnet, trąbka i skrzypce). W kolejnym etapie treningu poziom trudności się zwiększał, a nadawane dźwięki zostały uzupełnione o dźwięki otoczenia (płacz dziecka, odgłosy zwierząt, ruch uliczny itp.).

2. W drugiej grupie zastosowano muzykoterapię aktywną pod nadzorem muzykoterapeuty. Podczas sześciu dwugodzinnych (z 15 minutową przerwą) sesji grupowych rehabilitacja obejmowała: ćwiczenia detekcji i różnicowania dźwięków, śpiewanie, grę na instrumencie, improwizację muzyki oraz rozumienie mowy. Zajęcia były w pełni interaktywne i wymagały zaangażowania ze strony uczestników. Pacjenci otrzymali do wypełnienia kwestionariusz składający się z 4 części: ocena percepcji rytmu, ocena percepcji muzyki, ocena umiejętności odtwarzania muzyki i subiektywna ocena swoich umiejętności w skali $1-10$.

3. W trzeciej grupie - kontrolnej - nie zastosowano metod rehabilitacji słuchu.

Nie wykazano istotnej różnicy pomiędzy zastosowaniem podejścia pierwszego i drugiego. W obu grupach po zakończeniu terapii pacjenci znacznie lepiej odróżniali barwę dźwięku, wysokość dźwięku oraz typ instrumentu w porównaniu do grupy kontrolnej. Wśród osób badanych wzrosła przyjemność płynąca z odbioru muzyki. W opinii autorów badania muzykoterapia powinna być stosowana jako część rehabilitacji słuchu u dorosłych użytkowników implantów ślimakowych [13].

\section{Wyniki i dyskusja}

Muzykoterapia u dorosłych użytkowników implantów ślimakowych nie jest jeszcze powszechną metodą rehabilitacji. Autorzy omówionych prac zastosowali różne formy ćwiczeń. Stosowali terapię pod okiem specjalisty na zajęciach $[9,10,13]$ oraz terapię $\mathrm{w}$ domu pacjenta przy pomocy programów komputerowych [9,11-13]. Muzykoterapia polegała na: ćwiczeniach różnicowania barwy i wysokości dźwięków [9-13], ćwiczeniach percepcji mowy [9,10], śpiewaniu, graniu na instrumentach, odwzorowywaniu rytmu [9]. Każda metoda zastosowana przez badaczy wpłynęła na poprawę umiejętności słuchowych dorosłych użytkowników implantów ślimakowych. Pacjenci biorący udział w rehabilitacji w porównaniu do grupy kontrolnej znacznie lepiej odróżniali zarówno barwę, jak i wysokość dźwięku [9,11-13], zmieniło się także ich postrzeganie muzyki - zaczęli jej chętniej i częściej słuchać $[10,13]$. Co więcej, ta forma rehabilitacji wpłynęła na poprawę samoakceptacji, i dobre samopoczucie uczestników. Wyniki badań wykazały także zadowolenie pacjentów z efektów muzykoterapii [10]. Autorzy wszystkich prac zalecają włączenie muzykoterapii jako formy rehabilitacji dorosłych użytkowników implantów ślimakowych.

\section{Wnioski}

1. Zastosowanie muzykoterapii u dorosłych użytkowników implantów ślimakowych nie jest powszechną 
metodą rehabilitacji, na co wskazuje niewielka liczba publikacji.

2. We wszystkich omówionych badaniach, zaprezentowanych w artykułach na temat muzykoterapii prowadzonej wśród dorosłych użytkowników implantów ślimakowych, osiągnięto pozytywne efekty tej formy rehabilitacji. Wyniki wykazały poprawę różnicowania wysokości i barwy dźwięków oraz rytmu. Uczestnicy badań po zakończeniu muzykoterapii odczuwają większą przyjemność ze słuchania muzyki.

3. Dokonany przegląd literatury potwierdza słuszność wprowadzania muzykoterapii jako powszechnej metody rehabilitacji dorosłych pacjentów z implantami ślimakowymi. Zasadna jest również kontynuacja badań w celu skonstruowania ogólnodostępnego programu tej terapii.

\section{Piśmiennictwo}

1. Peretz I, Zatorre RJ. Brain organization for music processing. Ann Rev Psychol, 2005; 56: 89-114.

2. Warren DJ. How does the brain process music? Clin Med (Lond.), 2008; 8(1): 32-36.

3. Thaut MH, Trimarchi PD, Parsons LM. Human Brain Basis of Musical Rhythm Perception: Common and Distinct Neural Substrates for Meter, Tempo and Pattern. Brain Sci, 2014(4): 428-52.

4. Lima JP de. Influência da musicoterapia em usuários de implante coclear (rozprawa doktorska). Faculdade de Medicina, Universidade de São Paulo, 2017.

5. Niedzielska G. Głuchota wrodzona. W: Audiologia kliniczna. Śliwińska-Kowalska M. (red.). Łódź: Mediton; 2005.

6. Gryczyński M, Pajor A. Zaburzenia wirusowe i bakteryjne narządu słuchu. W: Audiologia kliniczna. Śliwińska-Kowalska M. (red.). Łódź: Mediton; 2005.

7. Obrębowski A. Fizjologia i patologia słuchu. W: Protetyka słuchu. E. Hojan (red.). Poznań: Wydawnictwo Naukowe UAM; 2014.

8. Kamińska B, Siebert B. Podstawy rozwoju mowy u dzieci. Forum Medycyny Rodzinnej, 2012; 6(5): 236-43.
9. Petersen B, Mortensen MV, Hansen M, Vuust P. Singing in the key of life: A study on effects of musical ear training after cochlear implantation. Psychomusicology: Music, Mind, and Brain, 2012; 22(2): 134-51.

10. Hutter E, Argstatter H, Grapp M, Plinkert PK. Music therapy as specific and complementary training for adults after cochlear implantation: A pilot study. Cochlear Implants Int, 2015; 16(3): S13-21.

11. Gfeller K. Music therapy for children and adults who are deaf of hard of hearing. W: The Oxford Handbook of Music Therapy. Edwards J (red.). Oxford: OUP Oxford; 2016, s. 230-43.

12. Smith L, Bartel L, Joglekar S, Chen J. Musical Rehabilitation in Adult Cochlear Implant Recipients with a Self-administered Software. Otol Neurotol, 2017; 38(8): 262-67.

13. Fuller CD, Galvin JJ, Maat B, Başkent D, Free RH. Comparison of two music training approaches on music and speech perception in cochlear implant users. Trends Hear, 2018; 22: 2331216518765379. 
